\title{
Evidence for the Blake Event recorded at the Eemian archaeological site of Caours, France
}

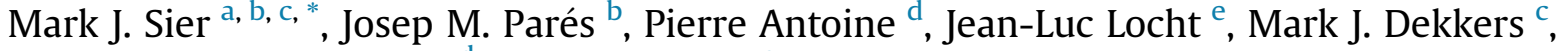 \\ Nicole Limondin-Lozouet ${ }^{\mathrm{d}}$, Wil Roebroeks ${ }^{\text {a }}$ \\ ${ }^{a}$ Faculty of Archaeology, Leiden University, P.O. Box 9515, 2300 RA Leiden, The Netherlands \\ b Centro Nacional de Investigación sobre la Evolución Humana (CENIEH), Paseo Sierra de Atapuerca 3, 09002 Burgos, Spain \\ ' Paleomagnetic Laboratory 'Fort Hoofddijk', Department of Earth Sciences, Faculty of Geosciences, Utrecht University, Budapestlaan 17, 3584 CD Utrecht, \\ The Netherlands \\ d Laboratoire de Geographie Physique, UMR 8591 CNRS, 1 Place Aristide Briand, F-92195 Meudon Cedex, France \\ e INRAP, 518 rue Saint-Fuscien, F-80000 Amiens, France
}

\section{A R T I C L E I N F O}

\section{Article history:}

Available online 11 June 2014

\section{Keywords:}

Blake Event

Eemian

Palaeolithic

Last Interglacial

Neandertal occupation of Britain

\begin{abstract}
A B S T R A C T
A palaeomagnetic study of the Last Interglacial calcareous tufa sequence at the archaeological site of Caours (northern France) identified a geomagnetic excursion that we interpret as the Blake Event. Earlier palaeontological (molluscs, mammals) and geochemical proxy studies at this site allowed recognition of full interglacial conditions prevailing during the deposition of the tufa sequence. The tufa sequence and associated Palaeolithic levels have been dated to the Eemian interglacial by a set of TIMS U/Th measurements on calcitic concretions (average : $123 \pm 3 \mathrm{ka}$ ). By previous correlations of the Blake Event with the Eemian sensu stricto (as defined in the Netherlands) pollenzones at Neumark Nord 2 (Germany) and Rutten (The Netherlands) it has been shown that the continental Eemian starts after the peak of Marine Isotope Stage (MIS) 5e. The identification of the Blake Event at Caours implies a post MIS 5e peak age for all four levels of the Palaeolithic occupation. In perspective of the time lag between the MIS 5e peak and the beginning of the Eemian identified in other studies, it is very likely that during the main occupation of Caours a significant barrier was in place between north western France and Great Britain, in the form of the English Channel. It is possible that the chronological position of the Last Interglacial environments in northwestern Europe in relation to sea-level change is a key factor behind the apparent absence of Last Interglacial Palaeolithic sites in Great Britain.
\end{abstract}

() 2014 Elsevier Ltd and INQUA. All rights reserved.

\section{Introduction}

The character of occupation of interglacial Europe by hominins has been a topic of a long debate. Extensive research has been devoted to finding the limits of European hominin occupation, both in time (e.g. Roebroeks and Van Kolfschoten, 1995; Carbonell et al., 2008) and in geographic space (e.g. Roebroeks et al., 1992; Parfitt et al., 2010). The geographic and environmental limits to the spatial distribution of specific hominins are of major interest, as they provide important information about hominin social and/or technological abilities to adapt to a specific ecosystem, or to find new ways of exploiting or competing for resources (e.g. Roebroeks, 2001; Dennell, 2003; Potts, 2012). Thus, improving the

\footnotetext{
* Corresponding author. Faculty of Archaeology, Human Origins Group, Leiden University, P.O. Box 9515, 2300 RA Leiden, The Netherlands.

E-mail address: marksier@gmail.com (M.J. Sier).
}

chronological and environmental framework of the pattern of hominin presence in a given region can provide us with data to infer changes in their behaviour as well as to assess the emergence of corridors or barriers that may have influenced their dispersal (e.g. Roebroeks and Kolfschoten, 1994; Speleers, 2000; Dennell and Roebroeks, 2005; Joordens et al., 2011). In this context, and due to its climate during the Palaeolithic, northwestern Europe has been considered a marginal area for hominin occupation, stretching to the limits the biological and cultural adaptations of its inhabitants (Roebroeks et al., 2011). This is also important during the Last Interglacial, in which Homo neanderthalensis dominated Europe. This warm and temperate period was first described as the Eemian by Harting (1874). Currently, the Eemian is defined by its terrestrial pollen zonation (Zagwijn, 1961). Due to the long research history in Europe and a relatively good preservation compared to previous interglacials, the Eemian has become a key period for study of the technological and social adaptations of $H$. neanderthalensis. 
In the early days of Palaeolithic research, interglacial Europe was seen as an ideal environment for hominins (Mortillet, 1883; Obermaier, 1912). Temperate interglacial climates were interpreted as periods in which survival and subsistence was relatively easy. Hominins could do without the protection of cliff overhangs and caves and thus move into regions that lacked these natural shelters (Mortillet, 1883), such as northern Europe. During the mid 1980s, this view shifted to the opposite side of the spectrum. Inspired by the work of Kelly (1983), who stated that most of the primary biomass in forested environments consists of plant leaves and stems which are difficult to access for hominins, Gamble (1986, 1987) postulated that interglacial northern Europe was actually a hostile environment for hominins. In his view, H. neanderthalensis, who was occupying more southern parts of Europe during the Last Interglacial, lacked the set of specialized skills and/or social structure which would have been necessary for successful exploitation of the resources in the forested northern regions (Gamble, 1986). The apparent lack of archaeological sites during this period in northern Europe gave support to Gamble's view. However, Roebroeks et al. (1992) refuted Gamble's hypothesis by presenting evidence that $H$. neanderthalensis was present in Europe in interglacial periods. Their extensive review of a number of northern European sites not only indicated the presence of $H$. neanderthalensis in pre-Eemian interglacial periods but also indicated occupation in mixed-oak forest (fully interglacial) environments of the Last Interglacial.

Still, many questions remain to be answered regarding the character of Neandertal occupation of northern Europe and the adaptations and abilities required for long-term occupation of this region. Although there is plenty of evidence suggesting that Neandertals were able to colonize middle latitudes up to $55^{\circ} \mathrm{N}$, it has been suggested that their presence in northern environments was discontinuous and strongly influenced by climatic fluctuations (Hublin and Roebroeks, 2009). Environmental degradation may have obliged $H$. neanderthalensis to search for southern refuges for survival, although local extinctions due to the harsh climatic conditions cannot be excluded either (e.g. Hublin and Roebroeks, 2009; Roebroeks et al., 2011).

One region of Europe which seems to have remained unoccupied during the Last Interglacial is Great Britain, where unambiguous traces of Last Interglacial Middle Palaeolithic sites are absent. However, the archaeological record is strongly biased, and various workers have stressed the role of preservation processes in this apparent absence (Roebroeks et al., 1992; Roebroeks and Speleers, 2002). Explaining the absence of Neandertals in Great Britain could give valuable insight about migration speeds, migration barriers or preferred habitats of $H$. neanderthalensis. Ashton (2002) proposed two hypotheses to explain the lack of human occupation in Great Britain during the Last Interglacial. The first one, termed "insularity of Britain", explains the absence of Neandertals as the result of fast sea level rise during the Last Interglacial; the newly formed English Channel between Great Britain and France would have acted as a barrier for the Neandertal expansion. In the second model, focussing on "climatic extremes and the occupation of northwest Europe", the absence is explained as the result of the preference of Neandertals for mammoth-steppe-like environments in the eastern regions of Europe. This preference would explain the presence of Last Interglacial archaeological sites for instance in Germany, as well as their absence in the more Atlantic parts of northern Europe, which lacked a mammoth-steppe type of environment during the Eemian.

Related with both models, studies about the hominin occupation of northwest France have become key for understanding the character of Neandertal occupation in northern Europe in general, and in Great Britain in particular. Despite a long research history, no unambiguous traces of occupation during the Eemian were discovered in northwest France (Roebroeks and Speleers, 2002) until recently (Antoine et al., 2006; Locht et al., 2009). Research in the $1940 \mathrm{~s}$ and $1950 \mathrm{~s}$ at exposures at Caours $\left(50^{\circ} 07^{\prime} 53^{\prime \prime} \mathrm{N}\right.$; $01^{\circ} 52^{\prime} 59^{\prime \prime} \mathrm{E}$, Fig. 1), situated on a tributary of the Somme river near the town of Abbeville (northern France), however had yielded some tantalizing evidence in the form of Levallois flakes and an interglacial fauna (Breuil, 1952; Breuil and Barral, 1955; Bourdier, 1974), as noted by Roebroeks and Speleers (2002).

Recent multidisciplinary studies have now enabled the unambiguous identification of Caours as Eemian in age. The site contains large numbers of in situ Palaeolithic flint artefacts and faunal remains (Antoine et al., 2006). The site is situated on a terrace $6 \mathrm{~m}$ above the current valley floor and on basis of its position in the terrace system, the Caours fluvial sequence has been correlated to Marine Isotope stage (MIS) 6/5 (Antoine et al., 2006; Dabkowski et al., 2011). The sediments are dominated by carbonate tufa and contain abundant fossil remains (large mammals, micro-mammals, molluscs, leaf imprints). The fossils represent a temperate fauna indicating an Eemian age for the site (Breuil and Barral, 1955; Antoine et al., 2006). This age assessment is supported by ten $U /$ Th (TIMS) ages of the tufa of $\sim 120 \mathrm{ka}(123 \pm 3 \mathrm{ka}$ ) (Antoine et al., 2006), thermoluminescence ages of heated flints of $127.2 \pm 10.4 \mathrm{ka}$ and $119.6 \pm 9.3 \mathrm{ka}$ (Locht et al., 2009), and electron spin resonance (ESR) age determinations of a deer molar of $124 \pm 15 \mathrm{ka}$ (Bahain et al., 2010). The ongoing work at Caours unambiguously confirms the Last Interglacial presence of $H$. neanderthalensis in this region of Europe. Thus, the site plays a major role in our understanding of human occupation and migration to this region of Europe during the Last Interglacial.

While the ages are reasonably well-constrained, having a tighter age control on the four layers with Neandertal artefacts in Caours would help with its interpretation and facilitate comparison to other sites in northwest Europe of similar age. The site is located directly south of the English Channel and could potentially yield information regarding the accessibility of Great-Britain in the Last Interglacial, giving support to one of the hypotheses for the absence of human occupation in Great Britain mentioned above (Ashton and Lewis, 2002).

This paper reports the result of a study which attempted to constrain the period of Neandertal presence at Caours by the identification of the palaeomagnetic Blake Event which is tightly correlated to the Eemian. The Blake Event was discovered in 1969 in a core from the Bermuda rise in the Atlantic Ocean (Smith and Foster, 1969). It is a period with transitional to reversed directions of the earth's magnetic field (e.g. Merrill and McFadden, 1994; Langereis et al., 1997; Laj and Channell, 2007). Estimates of its duration are notably variable, ranging from less than 1000 to over 10,000 years (e.g. Nowaczyk et al., 1994; Channell et al., 2012). The Blake Event has also been correlated to the Eemian pollen zonation of northwestern and Central Europe (Sier et al., submitted for publication, 2011). At the time of palaeomagnetic sampling for the present Caours study, the Blake Event was correlated with the early part of the Eemian (e.g. Sier et al., 2011). However, a recent study of an oriented undisturbed core, taken at the Rutten site, in the region of the Eemian type locality in the Netherlands, provides evidence that the Blake Event may have lasted throughout most of the Eemian in northwest Europe or Eemian sensu stricto (Sier et al., submitted for publication). Even with this new evidence which implies that finding the Blake Event provides less tight time constraints than previously thought, its identification at Caours would firmly place the archaeology-yielding sediments in the Eemian sensu stricto. In the Neumark Nord and Rutten studies, the Blake Event was used to correlate the terrestrial Eemian record to the Marine Isotope Stage (MIS) record. Based on our correlation, we 


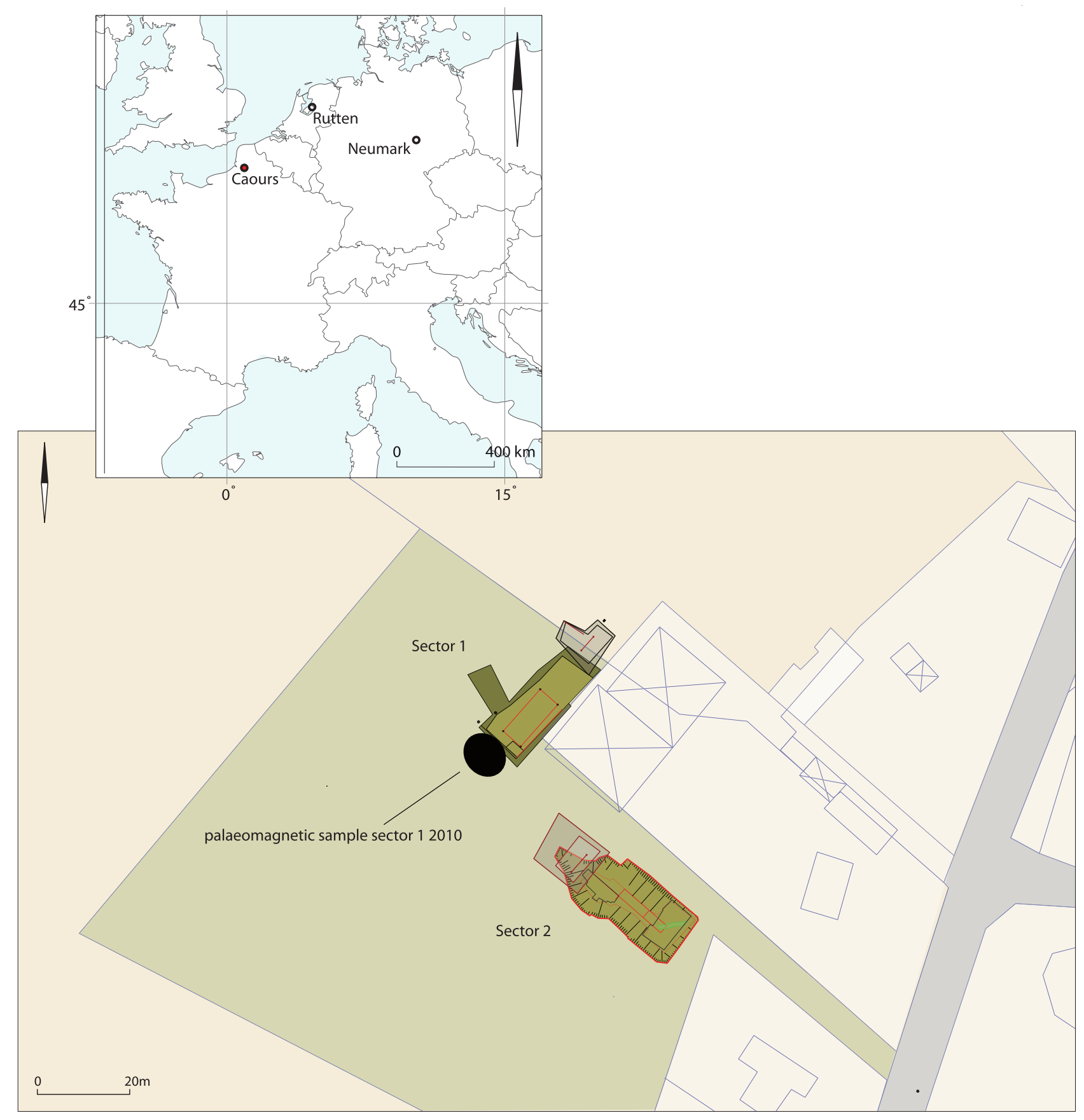

Fig. 1. Location and excavation map of the site of Caours (France), with the geographic location of Rutten (The Netherlands) and Neumark (Germany).

estimated that the Eemian lasted from $\sim 120.5 \mathrm{ka}$ to $109.5 \mathrm{ka}$ $( \pm 0.5 \mathrm{ka})$ (Sier et al., submitted for publication, 2011). More importantly, in the context of the present paper, the correlation of the Eemian with the MIS record situates the Eemian in northwest and central Europe well after the MIS 5e peak. This would mean that already during the first phases of the Eemian sensu stricto, high sea levels in the English Channel would have been in place constituting a strong physical barrier for hominin movements from France into Great Britain.

A second topic of the study presented here is to collect more data that can help to document the behaviour of the magnetic field during the period of the Blake Event. If the Blake record would show convincing fully reversed directions this would imply a dipolar nature of the geomagnetic field during at least part of geomagnetic events. If directions strongly deviating from normal secular variation would be found but not antipodal directions, this would imply a complex configuration of the geomagnetic field during excursions. Available data for Europe show 'mixed' results. For example, Reinders and Hambach (1995) published palaeomagnetic directions from a $130 \mathrm{~cm}$ thick loess profile from the Eifel (Germany) for which "no stable endpoint could be determined", but some levels were interpreted as fully reversed. Other samples show more intermediate directions. The Blake Event is recognized in sediments at Neumark Nord 2 (NN2) (Germany) (Sier et al., 2011) and at Rutten (the Netherlands) (Sier et al., submitted for publication) mainly by excursional declinations which, 
however, are not fully reversed. In many cases the inclinations were shallow but remained normal or with non fully reversed VGPs as also found in the sequence of Wels-Aschet in Austria (Scholger and Terhorst, 2013). This is in contrast to the Blake Event as recognized in other areas in the Northern Hemisphere (e.g. Smith and Foster, 1969; Bourne et al., 2012) where often fully negative inclinations were identified. However, even in the Mediterranean record (Tucholka et al., 1987), many of the palaeomagnetic directions are not fully reversed. The authors suggested that these directions were altered as the result of post-depositional processes. Confirmation of Rutten and NN2 type of palaeomagnetic directions for the Blake Event at Caours could help to give important insights on the behaviour of the palaeomagnetic field during the Blake Event.

To summarize, the main goal of this study is to identify the palaeomagnetic Blake Event in the Caours sediments. This identification could confirm the Eemian sensu stricto age of the site and would allow a more precise positioning of the hominin occupation at Caours on the global (MIS) sea-level curve. This research would potentially provide new data on the character of the occupation of northwestern Europe by Neandertals and would allow the discussion of more specific scenarios such as the absence of humans during the Last Interglacial in Great Britain.

\section{Methods and sampling}

Palaeomagnetic samples were taken during the 2009 and 2010 excavations of the Caours site at sector 1 and 2. The geological units (See Supplementary Information (SI) for description of the units) consist of a basal periglacial fluvial gravel (flint and chalk: $\sim 3 \mathrm{~m}$ ), overlain by calcareous silts $(\sim 0.6 \mathrm{~m})$ and then by carbonate tufas $(\sim 3.5 \mathrm{~m})$. The tufas have a range from fine-grained laminated to massive porous tufa. The type of tufa had its direct bearing on its sample potential, with the fine-grained units yielding a significant higher amount of samples. In total, 78 samples were taken, 46 samples for Alternating Field (AF) demagnetization, and 32 samples for Thermal (TH) demagnetization of the natural remanent magnetization (NRM). In addition, five hand samples of various dimensions were taken in order to identify the main magnetic carriers within the sediment. All studied geological units were sampled with dedicated sample containers for both $\mathrm{AF}$ and $\mathrm{TH}$ demagnetization. AF samples taken were collected with perspex containers, whereas for TH samples custom-made quartz glass containers were used. Both sample container types have standard palaeomagnetic dimensions ( $25 \mathrm{~mm}$ diameter and $22 \mathrm{~mm}$ height) and were gently pushed into freshly prepared sections. One oriented hand sample was of sufficiently large size to be sub-sampled, in the laboratory, with a $36 \mathrm{~cm}$ long u-channel. A u-channel is a plastic container with a square 2 by $2 \mathrm{~cm}$ cross-section and clip-on lid (Weeks et al., 1993). The u-channel was measured intact with a measurement interval of $2 \mathrm{~cm}$. Measurements of the samples were done within a couple weeks after retrieval of the samples to minimize possible alteration. During this period the samples remained in a cold storage $\left(<5{ }^{\circ} \mathrm{C}\right)$.

AF demagnetization was done with a robotized 2G DC-SQUID magnetometer with in-line AF demagnetization at the palaeomagnetic laboratory "Fort Hoofddijk" (Utrecht, The Netherlands). The instrument's sensitivity is $3 \times 10^{-12} \mathrm{Am}^{2}$; typical sample magnetic moments were at least two orders of magnitude higher. The instrument set-up is housed inside a magnetically shielded room (residual field $<200 \mathrm{nT}$ ). The robotized interface for field regulation and sample manipulation was built in-house. Up to 96 samples contained inside dedicated cubic holders (edge $30 \mathrm{~mm}$ ) are loaded onto a sample plateau and the robot loads them in batches of eight onto a tray that slides through the magnetometer and AF demagnetization coils. Samples are processed fully automatically with the so-called 'three position protocol' that compensates for the magnetic moment of the transport tray. This ensures optimal processing of weakly magnetic samples. Maximum demagnetization field was $100 \mathrm{mT}$ (see SI for step details).

Thermal demagnetization of the NRM was performed with an ASC thermal demagnetizer (residual field $<20 \mathrm{nT}$ ) at CENIEH, Burgos (Spain). Maximum demagnetization temperature was $630^{\circ} \mathrm{C}$. The remaining NRM was measured after each step with a SRM 755 4K DC-SQUID magnetometer (with built-in AF demagnetizer, instrument sensitivity $3 \times 10^{-12} \mathrm{Am}^{2}$, typical sample NRM magnetic moments were at least a couple of orders of magnitude higher) with a low-field ( $<5 \mathrm{nT})$ environment at the sample loading position. The u-channel was demagnetized and measured with the same equipment up to a maximum AF peak field of $100 \mathrm{mT}$.

For rock-magnetic purposes hand samples were measured to better understand their magnetic properties in support of the interpretation of the ChRM directions. A selection of samples was pulsed in three perpendicular axes according to Lowrie (1990). Maximum field was $1 \mathrm{~T}$, intermediate field $0.4 \mathrm{~T}$ and the low field $0.12 \mathrm{~T}$. Thermal demagnetization was performed up to a maximum temperature of $600{ }^{\circ} \mathrm{C}$ in 16 steps (see SI for details).

\section{Results}

\subsection{Palaeomagnetism}

Intensities of the NRM range from $1.7 \cdot 10^{-5} \mathrm{~A} / \mathrm{m}$ to $1.0 \cdot 10^{-2} \mathrm{~A} / \mathrm{m}$ (see SI Table 1), well above the background noise of the magnetometers used in this study. Demagnetization results were analyzed by visual inspection of orthogonal demagnetization diagrams (Zijderveld, 1967) using the "Fort Hoofddijk" "paldir" software. Directions of the Characteristic Remanent Magnetisation (ChRM) were calculated using least-squares principal component analysis (Kirschvink, 1980) on at least 4 steps. Four different quality labels were assigned to the ChRM directions, with only quality 1 and quality 2 ChRM directions being used for interpretation. ChRM directions from samples of quality 1 are those with vector end points close to the origin (quality 1, see Fig. 2A-C). Quality 2 diagrams are trending to the origin but not reaching it, or have their endpoint slightly offset from the origin. ChRM directions were anchored on the origin (Fig. 2D). Noisy diagrams with maximum angular deviation (MAD) below $15^{\circ}$ or diagrams which show indications of a not completely resolved ChRM component during high demagnetization levels (which cannot be calculated with 4 steps but do from a great-circle) are given quality 3 (Fig. 2E). Quality label 4 samples are 1) samples with the minimum of 4 steps that however disintegrated in an early stage during measuring, 2) were completely demagnetized at an early stage in the stepwise progressive demagnetization procedure (below $20 / 30 \mathrm{mT}$ or $360^{\circ} \mathrm{C}$ ), or 3 ) have MADs $>15^{\circ}$. In all other diagrams, ChRM components were not resolved ( 37 out of 96 samples, see Table 1 of the Supplementary Information).

The ChRM directions for the samples treated with AF demagnetization were typically determined between 15 and $60 \mathrm{mT}$ AF steps (occasionally up to a maximum of $80 \mathrm{mT}$ ). No indications of gyroremanent magnetization (GRM) were observed during AF demagnetization. ChRM directions from the thermal demagnetization are not based on a typical set of temperatures; minimum temperatures vary from $230{ }^{\circ} \mathrm{C}$ to $300{ }^{\circ} \mathrm{C}$. Upper temperatures show a broad range: from as low as $360{ }^{\circ} \mathrm{C}$ to as high as $600{ }^{\circ} \mathrm{C}$. Notably varying upper temperatures can even occur within a single geological unit; it indicates that different magnetic minerals carry the ChRM directions. In a few Zijderveld diagrams, clear overprints were identified. As an example, Fig. 2A shows an overprint from 0 to $35 \mathrm{mT}$, on an excursional ChRM. In other samples it is not that clear-cut. In sample C70 (SI Fig. 2) the ChRM direction in the 

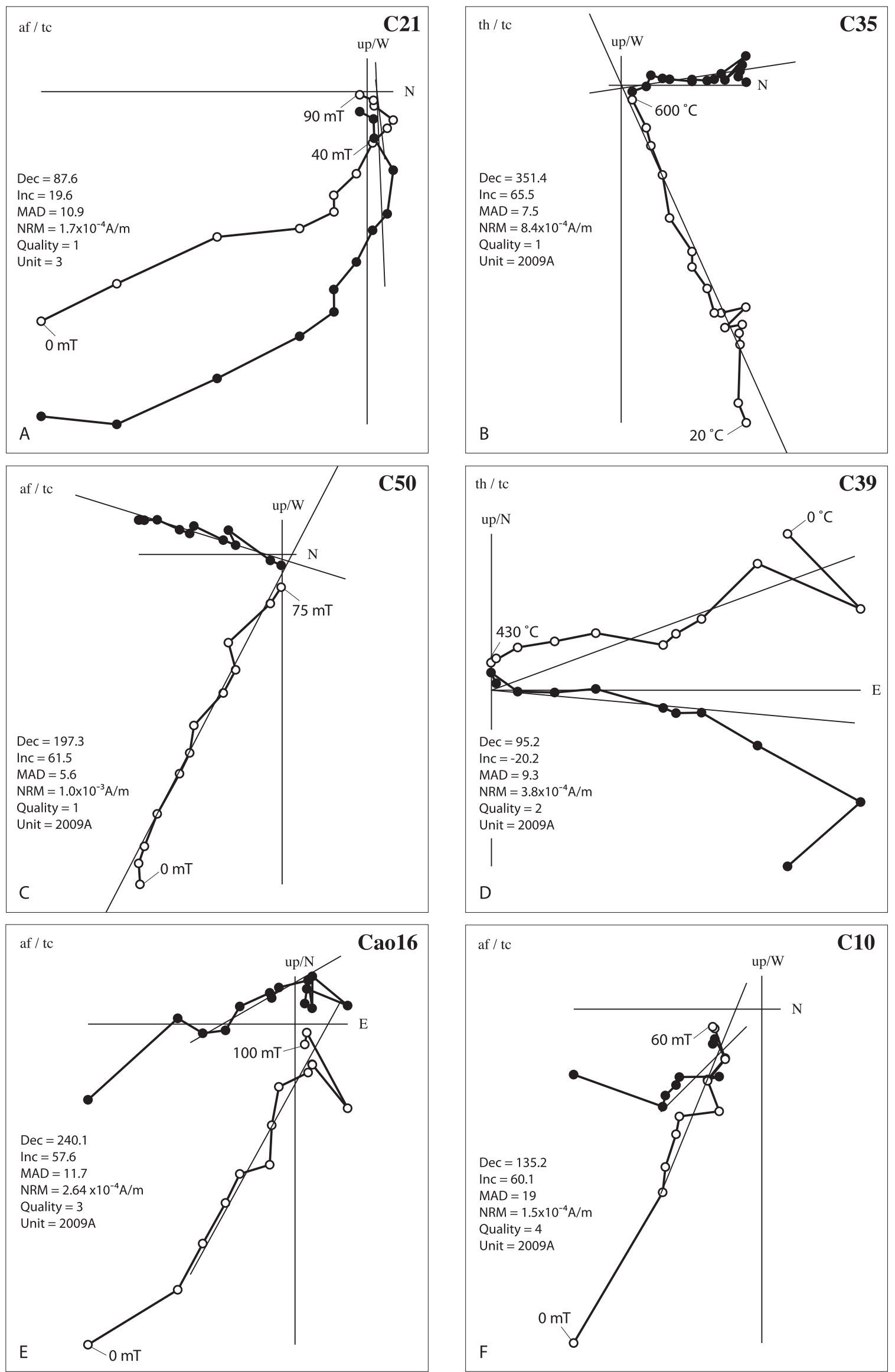

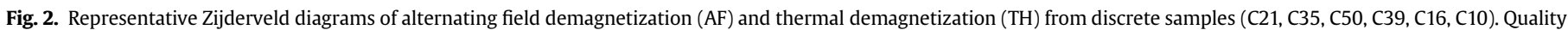
1 samples are in panels A, B and C, quality 2 in panel D, quality 3 in panel E, quality 4 in panel F. No tectonic correction was applied for these samples. 

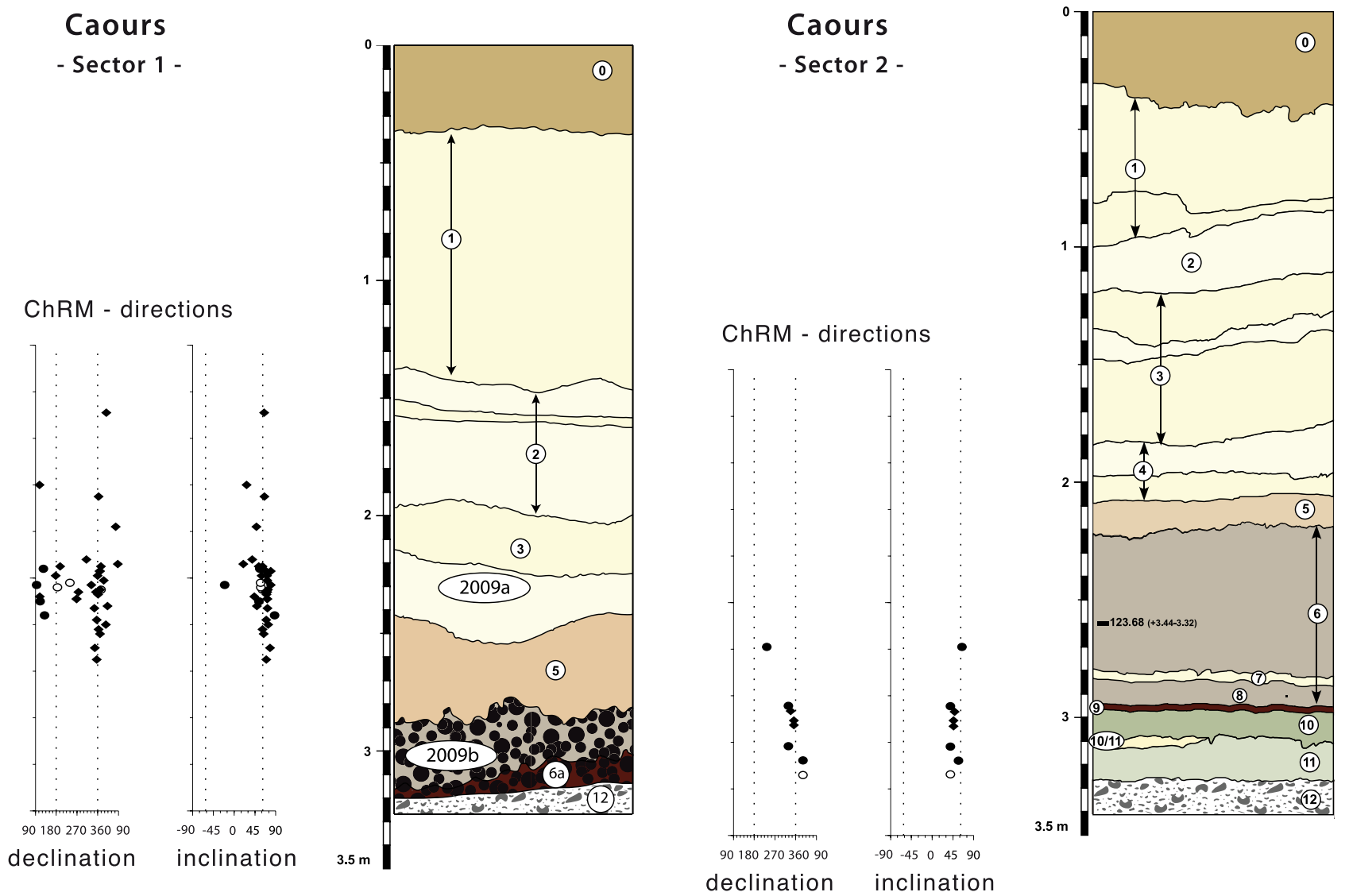

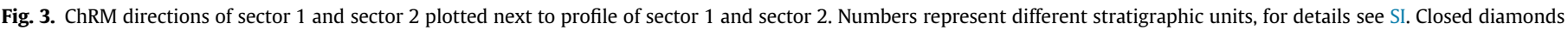
are quality 1 ChRM directions, closed circles are quality 2 ChRM directions and open circles are quality 3 ChRM directions.

Zijderveld diagram is not trending toward the origin; it may develop into an excursional direction. This, however, cannot be determined with certainty because consecutive demagnetization steps do not show a linear trend. The last steps are situated on a great circle trajectory. This is indicative of two NRM components being demagnetized simultaneously but each to a different extent. Therefore, they span up a plane that is displayed as great circle in equal area projection. Precise calculation of both directions is only possible under certain constraints which are unfortunately not met by this data set. There appears to be a strong relation between the NRM intensity and the quality of the Zijderveld diagrams: intensities above $10^{-4} \mathrm{~A} / \mathrm{m}$ give significantly better results than samples with lower NRM intensities (SI Table 1). However, the polarity of the ChRM directions is not related to the NRM intensity.

No fully reversed ChRM directions are identified, but of the 59 samples (including the $18 \mathrm{u}$-channel measurements, SI Table 1) that were given a quality label (between 1 and 4), 23 have virtual geomagnetic poles (VGP's) that deviate more than $40^{\circ}$ of the expected VGP position (SI Table 1) and can be labelled "excursional" (Merrill and McFadden, 1994). Excursional directions are present throughout the sampled units (Fig. 3 and SI Table 1). Excursional directions are primarily the result of the deviating declinations, while the inclination in all but one case remained downwards (normal).

\subsection{Magnetic mineralogy}

To document the magnetic mineralogy, thermal demagnetization of 3 axial Isothermal Remanent Magnetisation (IRM) was carried out on a selection of samples from several units (Fig. 4 and SI Fig. $1 \mathrm{a}-\mathrm{d}$ ). The splitting of the IRM into three coercivity fractions along orthogonal axes enables to analyse their temperature dependence individually (Lowrie, 1990). The "hard" coercivity fraction with coercivities $>400 \mathrm{mT}$ is insignificant in the Caours sediments; their magnetic mineralogy is dominated by "medium" (120-400 mT) and particularly "soft" (<120 mT) coercivity. No goethite is traced in the hard fraction because there is no determined maximum unblocking temperature at $\sim 100{ }^{\circ} \mathrm{C}$. The amount of the other high-coercivity mineral, hematite, is small. At $600{ }^{\circ} \mathrm{C}$

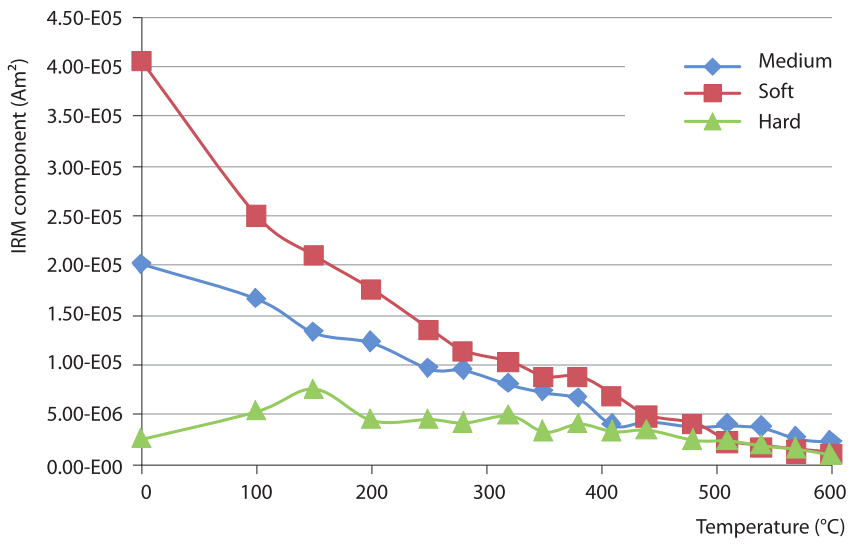

Fig. 4. Thermal demagnetization of 3 axes Isothermal Remanent Magnetisation (IRM) Maximum field was $1 \mathrm{~T}$, intermediate field $400 \mathrm{mT}$ and low field $120 \mathrm{mT}$. Sample was taken from geological unit 5 ( $\mathrm{cf} \mathrm{SI).}$ 
the remaining IRM was already at the interpretational limit (directions became erratic so no meaningful results could be calculated anymore) and the thermal demagnetization was stopped after that temperature. The IRM smoothly decays to a maximum unblocking temperature slightly higher than $500{ }^{\circ} \mathrm{C}$ in the medium and soft fractions. This indicates fine-grained magnetite as the maximum unblocking temperature is still distinctly lower than $580{ }^{\circ} \mathrm{C}$, the maximum unblocking temperature of pure nonsubstituted magnetite $\left(\mathrm{Fe}_{3} \mathrm{O}_{4}\right)$. The lower maximum unblocking temperature can be explained by substitution of primarily $\mathrm{Ti}$ in the magnetite or by a small grain size. In this sedimentary setting, titanium-substituted magnetite (with a volcanic provenance) is very unlikely, so the low maximum unblocking temperature is presumably due to fine particles. No break-in-slope was observed around $300{ }^{\circ} \mathrm{C}$ which would indicate the presence of diagenetic greigite $\left(\mathrm{Fe}_{3} \mathrm{~S}_{4}\right)$. Its absence was already inferred from GRM not being observed. The thermal demagnetization of the IRM supports this notion.

\section{Discussion and conclusion}

The quality of the Zijderveld diagrams and the intensity of the NRM show a positive correlation. There is no clear relation between the direction of the ChRM and the quality of the Zijderveld diagrams. The geological units sampled (see Fig. 3), except unit 7, yielded Zijderveld diagrams of quality 2 or 1 . All geological units above unit 7 have high quality Zijderveld diagrams with VGPs of over $40^{\circ}$ deviation of the expected VGP position (SI Table 1 ) which are considered as excursional (e.g. Merrill and McFadden, 1994). Unit $6 \mathrm{a}, 6 \mathrm{~b}$ (coarse fluvial gravels, see SI) have not been sampled and unit 8 was sampled unsuccessfully, whereas units 9 and 10 give both directions of normal polarity in samples of high quality and excursional in some of the lower quality samples. As only high quality ChRM directions are included in the interpretation, these units are interpreted to have normal palaeomagnetic polarity. Based on the position of the Caours terrace in the Somme valley terrace sequence, given the presence of warm-temperate animals, and in view of the numerical age estimates (Antoine et al., 2006; Bahain et al., 2010) which suggest a Last Interglacial age for the sediments, we interpret these excursional (not fully reversed) directions as the Blake Event. These ages also exclude a so-called "Post Blake Event" assignation which, if accepted, has a much younger age of c. $94.1 \pm 7.8 \mathrm{ka}$ (e.g. Jicha et al., 2011). The entire period between $\sim 120 \mathrm{ka}$ and $\sim 100 \mathrm{ka}$ is characterized by a low intensity of the Earth's magnetic field (Valet et al., 2005) which would make the chance that excursions or even reversals of the field occur higher than for other periods. However, changes in palaeomagnetic directions during 100-120 ka are described only at the older age range (Blake Event) and, occasionally, at the younger age range (post-Blake). The Blake Event consists in some localities (e.g. Lanzhou section, Fang et al., 1997) of two reversed parts interrupted by a brief period of normal polarity, although it is also known for its elusiveness (Parés et al., 2004). The zones of normal polarity within the Blake Event have been observed in several locations from various parts of the globe (e.g. Fang et al., 1997; Thouveny et al., 2004). In one publication of the Jiuzhoutai section (Lanzhou, western Loess Plateau, China) even three zones with excursional or reversed directions were identified as the Blake Event (Zhu et al., 1994). In addition, recent studies have given support for a rather long duration of the Blake Event. These studies suggest a duration of at least 6000 years (Bourne et al., 2012) and possibly 8000 years or longer (Bourne et al., 2012; Sier et al., submitted for publication) and in strong correlation with the Eemian sensu stricto (Sier and Dekkers, 2013; Sier et al., submitted for publication, 2011). Channell et al. (2012), on the other hand, propose a short duration of 1-2 ka for the Blake Event, because they based their inference on the presence of fully reversed inclinations straddled by intermediate directions.

The lower boundary of the Blake Event at Caours is potentially situated between unit 7 and 9 (note: at Caours units are labelled from top to bottom), as the higher quality ChRM directions all have a normal direction. However, ChRM directions of lower quality (SI Table 1) show excursional directions, but we refrain from interpreting those due to their low quality. The lower boundary of the Blake would identify these Caours sediments as late Saalian in age if we correlate with the NN2 and Rutten sites. At NN2 the lower boundary of the Blake Event was identified in late Saalian age sediment (Sier et al., 2011). At the site of Rutten this boundary could not be identified with certainty, though a late Saalian age is likely based on the stratigraphic position of the sediments (Sier et al., submitted for publication).

The numerical ages of the concerned units at Caours (Antoine et al., 2006) fall well within the estimated ages and durations of the Blake Event (Sier et al., submitted for publication, 2011). Fossils found at the lower units of the Caours sequence, between units 10 and 11 (archaeological level 4), also suggest fully temperate conditions (Antoine et al., 2006; Locht et al., 2009). More importantly, the study of the malacological succession at Caours shows that unit 10 , and the contemporaneous Palaeolithic level N4, is fully interglacial (Limondin-Lozouet, 2011). Considering this evidence, we interpret that the lower part of the Caours section is most likely of Blake Event age, at least up to the unconformity that separates unit 10 and unit 11 underneath. This unit 11 contains evidence of a cold climate malacological assemblage (Limondin-Lozouet, 2011) pointing to a Saalian age.

At NN2 and Rutten, the Blake Event has been identified in conjunction with an Eemian pollen record, together in the same sections and core, respectively. From this we can infer that the Caours sediments not only record the Blake Event age but can be considered of Eemian sensu stricto age as defined at its type locality (Zagwijn, 1961). This is in agreement with numerical and biostratigraphic ages derived in the previous studies (Breuil and Barral, 1955; Antoine et al., 2006, 2007; Bahain et al., 2010; Limondin-Lozouet, 2011).

Another aspect worth mentioning is the lack of fully reversed directions at Caours, similar to the Rutten site (Sier et al., submitted for publication) and the NN2 locality (Sier et al., 2011). Together, the data of Caours, NN2 and Rutten seem to suggest that these excursional directions, rather than truly reversed directions, characterize the Blake Event in northwest and central Europe. On the other hand, one could argue that the ChRM directions identified here are the result of secondary processes which affected the original ChRM directions. Compaction, for example, is known to bias palaeomagnetic inclinations by making them shallower (e.g. Tauxe, 2011; Kodama, 2012). The young sediments at Caours, however, have undergone very little compaction, because they were never buried deeply. However, palaeomagnetic declinations should not be affected by compaction. Processes such as delayed lock-in time, and formation of new magnetic minerals, are possibly present in all sedimentary settings and certainly might complicate a straightforward interpretation of ChRM directions (e.g. Tauxe, 2011; Kodama, 2012). We believe we have arguments to infer that the lack of fully reserved directions is not due to the processes mentioned above, but rather to a combination of several factors such as weak NRM intensities, and occasionally large overprint components, making the isolation of the primary ChRM component direction difficult. The study presented here and our other work on the Blake Event in Rutten (Netherlands) and Neumark Nord2 (Germany) were conducted in distinct and different sedimentary settings. Caours is in tufa setting in which a depositional, or 
possibly a quickly formed biogenic-induced chemical remanence, of fine-grained magnetite with small amounts of hematite is responsible for the recording of the ChRM. Rutten has a fluviatile setting (Busschers et al., 2007; Jan et al., 2014) dominated by ironsulfides (Sier et al., submitted for publication). Neumark Nord 2 is situated in a small shallow basin (Eissmann, 2002; Mania and Mania, 2008) in which the ChRM is recorded by magnetite and hematite (Sier and Dekkers, 2013). In all three sites, very few of the palaeomagnetic directions can be labelled as "fully reversed". Two papers published in 2013 reported on the identification of the Blake Event derived from similar directions. Scholger and Terhorst (2013) identified the Blake Event in a Loess sequence in Wels-Aschet (Austria) based on VGP latitude values of around $-10^{\circ}-5^{\circ}$, clearly corresponding to not fully reversed orientations. Baltrūnas et al. (2013) published palaeomagnetic data of the Netiesos section in southern Lithuania. Their lacustrine sediments yielded palaeomagnetic data in which the ChRM directions during the Eemian show great variability and a combination of both excursional and normal ChRM directions. Still, the possibility that in all these sites the ChRM directions do not reflect the true magnetic field due to incomplete demagnetization should not be excluded, given that a number of records of the Blake Event (in other regions) show fully reversed directions (e.g. Zhu et al., 1994; Bourne et al., 2012). However, stable endpoints are not always reached, as reported by Reinders and Hambach (1995).

While we are aware of a number of processes that could distort the NRM recording in sedimentary settings, it is noteworthy that several studies from the Blake Event in Europe seem to yield similar excursional but not fully reversed directions in different sedimentary settings. Do these sedimentary artefacts operate to the same extent in variable sediment settings? The answer is unknown at this stage, but the directional similarity in several European records could be a hint of the Blake Event having a somewhat more delicate structure than previously thought.

Fully reversed directions during, excursions reversals, or during short-duration polarity zones would imply a dominantly dipolar geomagnetic field. If intermediate but not fully reversed directions are observed in a given region (Europe) this would imply that higher-order geomagnetic phenomena would be of relevance. For example, Clement (2004) showed that reversal durations are dependent on site latitude, which opens a new debate on the role of non-dipolar components on the polarity changes. This issue, although beyond the scope of the present work, is central to modellers of the behaviour of the earth's geomagnetic field, but it also complicates the identification of the Blake Event in unoriented cores (e.g. most IODP cores, where declination is typically analyzed on a relative basis within individual core segments). For a truly meaningful distinction between these two options, high-quality directional records (preferably full-vector records) of the Blake in Europe are required. The Caours record is palaeomagnetically rather complicated in terms of the interpretation of ChRM directions precluding making firm statements at this stage. We hope that better quality recordings will be published in the future to settle this geomagnetic question.

The Blake Event has been directly linked to the Eemian pollen sequence which in turn has been correlated to the MIS record via the same event, positioning the Eemian sensu stricto and the Blake Event after the MIS 5e peak (Sier et al., submitted for publication; Sier et al., 2011). Placing the archaeological occupation layers of Caours within the Eemian sensu stricto is an important observation, indicating when Caours was occupied, but also that the occupation was well after the "window of opportunity" (as Ashton (2002) calls it) for range expansion into Great-Britain, i.e., before the Last Interglacial sea level maximum. This means that the "dry path towards Great Britain" was already submerged by high sea level for some time when Neandertals discarded their first stone artefacts at Caours (unit 10). The presence of a physical barrier in the form of the sea water in the English Channel may have been the main obstacle to a Last Interglacial occupation of England by Neandertals.

\section{Acknowledgements}

The research of Mark Sier has been funded by the N.W.O. Spinoza Price (036.001.364) awarded to Wil Roebroeks. Research partially funded by grant CGL2010-16821 awarded to Josep M. Parés. The team of Caours is thanked for their generous hospitality and Joanne Porck of geodesigns.arch@gmail.com for her work on the figures. The reviewers are thanked for their helpful comments which helped to improve this manuscript.

\section{Appendix A. Supplementary data}

Supplementary data related to this article can be found at http:// dx.doi.org/10.1016/j.quaint.2014.05.022.

\section{References}

Antoine, P., Limondin-Lozouet, N., Auguste, P., Locht, J.L., Galheb, B., Reyss, J. Escudé, E., Carbonel, P., Mercier, N., Bahain, J.J., Falguères, C., Voinchet, P., 2006. Le tuf de Caours (Somme, France): mise en évidence d'une séquence eemienne et d'un site paléolithique associé. Quaternaire 17, 281-320.

Antoine, P., Limondin Lozouet, N., Chaussé, C., Lautridou, J.P., Pastre, J.F., Auguste, P. Bahain, J.J., Falguères, C., Galehb, B., 2007. Pleistocene fluvial terraces from northern France (Seine, Yonne, Somme): synthesis, and new results from interglacial deposits. Quaternary Science Reviews 26, 2701-2723.

Ashton, N., 2002. Absence of humans in Britain during the last interglacial (oxygen isotope stage 5e). In: Tuffreau, A., Roebroeks, W. (Eds.), Publications du CERP. Université des sciences et technologies de Lille, Villeneuve-d'Ascq, France, pp. 93-103.

Ashton, N., Lewis, S.G., 2002. Deserted Britain: declining populations in the British Late Middle Pleistocene. Antiquity 76, 388-396.

Bahain, J.J., Falguères, C., Dolo, J.M., Antoine, P., Auguste, P., Limondin-Lozouet, N. Locht, J.L., Tuffreau, A., Tissoux, H., Farkh, S., 2010. ESR/U-series dating of teeth recovered from well-stratigraphically age-controlled sequences from Northern France. Quaternary Geochronology 5, 371-375.

Baltrūnas, V., Seiriene, V., Molodkov, A., Zinkute, R., Katinas, V., Karmaza, B., Kisieliene, D., Petrosius, R., Taraskevcius, R., Piliciauskas, G., Schmolcke, U., Heinrich, D., 2013. Depositional environment and climate changes during the late Pleistocene as recorded by the Netiesos section in southern Lithuania. Quaternary International 292, 136-149.

Bourdier, F., 1974. La « marne blanche » d' Abbeville, gisement type de l'Abbevillien. Quaternaire 11, 161-163.

Bourne, M., Mac Niocaill, C., Thomas, A.L., Knudsen, M.F., Henderson, G.M., 2012 Rapid directional changes associated with a 6.5 kyr-long Blake geomagnetic excursion at the Blake-Bahama Outer Ridge. Earth and Planetary Science Letters 333-334, 21-34.

Breuil, H., 1952. Glanes conchyliologiques en France (Nord et Sud-Ouest) determinées par A.S. Kennard. Congrès Préhistorique de France. Compte rendu de la XIIIe Session, 1950, pp. 191-240. Paris.

Breuil, H., Barral, L., 1955. Bois de Cervidés et autres os travaillés sommairement au Paléolitique ancien vieux monde et au Moustérien des grottes de grimaldi et de lóbservatoire de monaco. Bulletin du Musee d'anthropologie prehistorique de Monaco 2, 1-32.

Busschers, F.S., Kasse, C., van Balen, R.T., Vandenberghe, J., Cohen, K.M., Weerts, H.J.T., Wallinga, J., Johns, C., Cleveringa, P., Bunnik, F.P.M., 2007. Late Pleistocene evolution of the Rhine-Meuse system in the southern North Sea basin: imprints of climate change, sea-level oscillation and glacio-isostacy. Quaternary Science Reviews 26, 3216-3248.

Carbonell, E., Bermudez de Castro, J.M., Pares, J.M., Perez-Gonzalez, A., CuencaBescos, G., Olle, A., Mosquera, M., Huguet, R., van der Made, J., Rosas, A., Sala, R. Vallverdu, J., Garcia, N., Granger, D.E., Martinon-Torres, M., Rodriguez, X.P. Stock, G.M., Verges, J.M., Allue, E., Burjachs, F., Caceres, I., Canals, A., Benito, A., Diez, C., Lozano, M., Mateos, A., Navazo, M., Rodriguez, J., Rosell, J., Arsuaga, J.L., 2008. The first hominin of Europe. Nature 452, 465-469.

Clement, B.M., 2004. Dependence of the duration of geomagnetic polarity reversals on site latitude. Nature $428,637-640$.

Channell, J.E.T., Hodell, D.A., Curtis, J.H., 2012. ODP Site 1063 (Bermuda Rise) revisited: oxygen isotopes, excursions and paleointensity in the Brunhes Chron. Geochemistry Geophysics Geosystems 13, Q02001.

Dabkowski, J., Limondin-Lozouet, N., Antoine, P., Marca-Bell, A., Andrews, J., 2011 Recording interglacial climatic changes from stable isotopes of Pleistocene tufa calcite in northern france: examples from caours (Mis 5e; Somme) and la cellesur-seine (Mis 11; Seine-et-Marne). Quaternaire 22, 275-283. 
Dennell, R., 2003. Dispersal and colonisation, long and short chronologies: how continuous is the Early Pleistocene record for hominids outside East Africa? Journal of Human Evolution 45, 421-440.

Dennell, R., Roebroeks, W., 2005. An Asian perspective on early human dispersal from Africa. Nature 438, 1099-1104.

Eissmann, L., 2002. Quaternary geology of eastern Germany (Saxony, Saxon-Anhalt, south Brandenburg, Thüringia), type area of the Elsterian and Saalian Stages in Europe. Quaternary Science Reviews 21, 1275-1346.

Fang, X., Li, J., Van der Voo, R., Mac Niocaill, C., Dai, X., Kemp, R.A., Derbyshire, E. Cao, J., Wang, J., Wang, G., 1997. A record of the Blake Event during the last interglacial paleosol in the western Loess Plateau of China. Earth and Planetary Science Letters 146, 73-82.

Gamble, C., 1986. The Palaeolithic Settlement of Europe. Cambridge University Press, Cambridge.

Gamble, C.S., 1987. Man the shoveler: alternative models for Middle Pleistocene colonization and occupation in Northern latitudes. In: Soffer, O. (Ed.), The Pleistocene Old World. Regional Perspectives. Plenum Press, New York, pp. 81-98.

Harting, P., 1874. De bodem van het Eemdal. Verslagen en Verhandelingen Koninklijke Academie van Wetenschappen, pp. 282-290.

Hublin, J.J., Roebroeks, W., 2009. Ebb and flow or regional extinctions? On the character of Neandertal occupation of northern environments. Comptes Rendus Palevol 8, 503-509.

Jan Peeters, Freek S. Busschers, Esther Stouthamer, 2014. Fluvial evolution of the Rhine during the last interglacial-glacial cycle in the southern North Sea basin: a review and look forward, Quaternary International, Available online: 18 April 2014, ISSN 1040-6182, http://dx.doi.org/10.1016/j.quaint.2014.03.024.

Jicha, B.R., Kristjánsson, L., Brown, M.C., Singer, B.S., Beard, B.L., Johnson, C.M., 2011. New age for the Skálamaelifell excursion and identification of a global geomagnetic event in the late Brunhes chron. Earth and Planetary Science Letters 310, 509-517.

Joordens, J.C.A., Vonhof, H.B., Feibel, C.S., Lourens, L.J., van der Lubbe, H.J.L., DupontNivet, G., Sier, M.J., Davies, G.R., Kroon, D., 2011. An astronomically-tuned climate framework for hominins in the Turkana Basin. Earth and Planetary Science Letters 307, 1-8.

Kelly, R.L., 1983. Hunter-gatherer mobility strategies. Journal of Anthropological Research 39, 277-306.

Kirschvink, J.L., 1980. The least-square line and plane and the analysis of paleomagnetic data. Geophysical Journal of the Royal Astronomical Society 62, 699-718.

Kodama, K.P., 2012. Paleomagnetism of Sedimentary Rocks: Process and Interpretation. Wiley-Blackwell, Chichester.

Laj, C., Channell, J.E.T., 2007. Geomagnetic excursions. In: Kono, M. (Ed.), Geomagnetism. Treatise on Geophysics. Elsevier, Amsterdam, pp. 373-416.

Langereis, C.G., Dekkers, M.J., Lange, G.J., Paterne, M., Santvoort, P.J.M., 1997. Magnetostratigraphy and astronomical calibration of the last $1.1 \mathrm{Myr}$ from an eastern Mediterranean piston core and dating of short events in the Brunhes. Geophysical Journal International 129, 75-94.

Limondin-Lozouet, N., 2011. Successions malacologiques à la charnière Glaciaire Interglaciaire: du modèle Tardiglaciaire/Holocène aux transitions du Pléistocène. Quaternaire 22, 211-220.

Locht, J.L., Antoine, P., Auguste, P., Limondin Lozouet, N., 2009. Rapport de fouille programmée. Caours 2009 (Somme). Amiens. SRA Picardie, p. 40.

Lowrie, W., 1990. Identification of ferromagnetic minerals in a rock by coercivity and unblocking temperature properties. Geophysical Research Letters 17, 159-162.

Mania, D., Mania, U., 2008. La stratigraphie et le Paléolithique du complexe saalien dans la région de la Saale et de l'Elbe. L'Anthropologie 112, 15-47.

Merrill, R.T., McFadden, P.L., 1994. Geomagnetic field stability: reversal events and excursions. Earth and Planetary Science Letters 121, 57-69.

Mortillet, G. d, 1883. Le Préhistorique, antiquité de l'homme. C. Reinwald, Paris.

Nowaczyk, N.R., Frederichs, T.W., Eisenhauer, A., Gard, G., 1994. Magnetostratigraphic data from Late Quaternary sediments from the Yermak Plateau, Arctic ocean: evidence for four geomagnetic polarity events within the last $170 \mathrm{ka}$ of the Brunhes Chron. Geophysical Journal International 117, 453-471.

Obermaier, H., 1912. Der Mensch der Vorzeit. AVG, Berlin.

Parés, J.M., Van der Voo, R. Yan, M., 2004. After the dust settles: why is the Blake Event imperfectly recorded in Chinese Loess? In: Channell, J.E.T., Kent, D.V., Lowrie, W., Meert, J.G. (Eds.), Timescales of the Paleomagnetic Field.

Parfitt, S.A., Ashton, N.M., Lewis, S.G., Abel, R.L., Coope, G.R., Field, M.H., Gale, R. Hoare, P.G., Larkin, N.R., Lewis, M.D., Karloukovski, V., Maher, B.A., Peglar, S.M.,
Preece, R.C., Whittaker, J.E., Stringer, C.B., 2010. Early Pleistocene human occupation at the edge of the boreal zone in northwest Europe. Nature 466, 229-233.

Potts, R., 2012. Environmental and behavioral evidence pertaining to the evolution of early Homo. Current Anthropology 53, S299-S317.

Reinders, J., Hambach, U., 1995. A geomagnetic event recorded in loess deposits of the Tonchesberg (Germany): identification of the Blake magnetic polarity episode. Geophysical Journal International 122, 407-418.

Roebroeks, W., 2001. Hominid behaviour and the earliest occupation of Europe: an exploration. Journal of Human Evolution 41, 437-461.

Roebroeks, W., Conard, N.J., van Kolfschoten, T., 1992. Dense forests, cold steppes, and the palaeolithic settlement of northern Europe. Current Anthropology 33, $551-586$.

Roebroeks, W., Hublin, J.J., MacDonald, K., 2011. Continuities and discontinuities in Neandertal presence: a closer look at northwestern Europe. In: Ashton, N.M. Lewis, S.G., Stringer, C.B. (Eds.), Developments in Quaternary Science. Elsevier, Amsterdam.

Roebroeks, W., Kolfschoten, v. T., 1994. The earliest occupation of Europe: a short chronology. Antiquity 68, 489-503.

Roebroeks, W., Speleers, B., 2002. Last interglacial (Eemian) occupation of the North European plain and adjacent areas. In: Tuffreau, A., Roebroeks, W. (Eds.), Publications du CERP. Université des sciences et technologies de Lille, Villeneuved'Ascq, France, pp. 31-39.

Roebroeks, W., Van Kolfschoten, T., 1995. The Earliest Occupation of Europe. University of Leiden, Leiden.

Scholger, R., Terhorst, B., 2013. Magnetic excursions recorded in the Middle to Upper Pleistocene loess/palaeosol sequence Wels-Aschet (Austria). E\&G Quaternary Science Journal 62, 12-21.

Sier, M.J., Dekkers, M.J., 2013. Magnetic property analysis as palaeoenvironmental proxy: a case study of the Last Interglacial Middle Palaeolithic site at NeumarkNord 2 (Germany). In: Gaudzinski-Windheuser, S., Roebroeks, W. (Eds.), Multidisciplinary Studies of the Middle Palaeolithic Record from Neumark-Nord (Germany). LDASA, Halle.

Sier, M.J., Peeters, J., Dekkers, M.J., Parés, J.M., Chang, L., Busschers, F. S., Wallinga, J. Bunnik, F.P.M., Roebroeks, W., 2014. The Blake Event recorded near the Eemian Type locality: revised timing of the onset of the Eemian in north western Europe (submitted for publication).

Sier, M.J., Roebroeks, W., Bakels, C.C., Dekkers, M.J., Brühl, E., De Loecker, D., Gaudzinski-Windheuser, S., Hesse, N., Jagich, A., Kindler, L., Kuijper, W.J., Laurat, T., Mücher, H.J., Penkman, K.E.H., Richter, D., van Hinsbergen, D.J.J., 2011. Direct terrestrial-marine correlation demonstrates surprisingly late onset of the last interglacial in central Europe. Quaternary Research 75, 213-218.

Smith, J.D., Foster, J.H., 1969. Geomagnetic reversal in brunhes normal polarity epoch. Science 163, 565-567.

Speleers, B., 2000. The relevance of the Eemian for the study of the Palaeolithic occupation of Europe. Geologie en Mijnbouw 79, 283-291.

Tauxe, L., 2011. Essentials of Paleomagnetism. University of California Press, Berkeley and Los Angeles, California.

Thouveny, N., Carcaillet, J., Moreno, E., Leduc, G., Nérini, D., 2004. Geomagnetic moment variation and paleomagnetic excursions since 400 kyr BP: a stacked record from sedimentary sequences of the Portuguese margin. Earth and Planetary Science Letters 219, 377-396.

Tucholka, P., Fontugne, M., Guichard, F., Paterne, M., 1987. The Blake magnetic polarity episode in cores from the Mediterranean Sea. Earth and Planetary Science Letters 86, 320-326.

Valet, J.-P., Meynadier, L., Guyodo, Y., 2005. Geomagnetic dipole strength and reversal rate over the past two million years. Nature 435, 802-805.

Weeks, R., Laj, C., Endignoux, L., Fuller, M., Roberts, A., Manganne, R., Blanchard, E., Goree, W. 1993. Improvements in long-core measurement techniques: applications in palaeomagnetism and palaeoceanography. Geophysical Journal International $114,651-662$.

Zagwijn, W.H., 1961. Vegetation, climate and radiocarbon datings in the late Pleistocene of the Netherlands: I. Eemian and Early Weichselian, Nieuwe Serie. Mededelingen van de Geologische Stichting 14, 15-45.

Zhu, R.X., Zhou, L.P., Laj, C., Mazaud, A., Ding, Z.L., 1994. The blake geomagnetic polarity episode recorded in Chinese loess. Geophysical Research Letters 21, 697-700.

Zijderveld, J.D.A., 1967. Demagnetisation of rocks: analysis of results. In: Collinson, D.W., Creer, K.M., Runcorn, S.K. (Eds.), Methods in Palaeomagnetism. Elsevier, Amsterdam, pp. 254-286. 